\title{
Enantioselective Alkylation of Aldehydes Catalyzed by a Highly Active Titanium Complex of 3-Substituted Unsymmetric BINOL
}

\author{
Toshiro Harada* and Kousou Kanda \\ Department of Chemistry and Materials Technology, Kyoto Institute of Technology, \\ Matsugasaki, Sakyo-ku, Kyoto 606-8585, Japan \\ E-mail:harada@chem.kit.ac.jp
}

Table of Contents:

$\begin{array}{ll}\text { Preparation of Ligands } 2 \mathbf{a}-\mathbf{g} \text { and } 3 & \text { S-2 } \\ \text { Representative Procedure and Ee Determination } & \text { S-7 } \\ { }^{1} \text { H NMR and }{ }^{13} \text { C NMR Spectra of } 2 \mathbf{b} & \text { S-9, } 10 \\ { }^{1} \text { H NMR and }{ }^{13} \text { C NMR Spectra of 2e } & \text { S-11, } 12 \\ { }^{1} \text { H NMR and }{ }^{13} \text { C NMR Spectra of } 2 \mathbf{f} & \text { S-13, } 14 \\ { }^{1} \text { H NMR Spectrum of 1-(p-Methylphenyl)-1-propanol } & \text { S-15 } \\ { }^{1} \text { H NMR Spectrum of 1-(m-Methoxyphenyl)-1-propanol } & \text { S-16 } \\ { }^{1} \text { H NMR Spectrum of 1-(o-Chlorophenyl)-1-propanol } & \text { S-17 } \\ { }^{1} \text { H NMR Spectrum of 1-(1-Naphthyl)-1-propanol } & \text { S-18 } \\ { }^{1} \text { H NMR Spectrum of 1-(2-Naphthyl)-1-propanol } & \text { S-19 } \\ { }^{1} \text { H NMR Spectrum of 1-Phenyl-3-pentanol } & \text { S-20 } \\ { }^{1} \text { H NMR Spectrum of (E)-1-Phenylpent-1-en-3-ol } & \text { S-21 }\end{array}$ 
General. All chemicals were purchased commercially and used as received unless otherwise noted. THF was dried and distilled over sodium benzophenone ketyl. (R)-3Phenylethynyl-1,1'-bi-2-naphthol (2a) ${ }^{1}$ and $(R)-3,3^{\prime}$-Diphenyl-1,1'-bi-2-naphthol $(\mathbf{3})^{2}$ were prepared according to the literature procedure.

(R)-3-Bromo-1,1'-bi-2-naphthol (2b). To a THF (45 mL) solution of $(R)-2,2$ 'bis(methoxy(methoxy))-1,1'-binaphthyl $(1.00 \mathrm{~g}, 2.67 \mathrm{mmol})$ at $-78{ }^{\circ} \mathrm{C}$ under nitrogen was added $t$-BuLi (2.2 mL, $3.3 \mathrm{mmol}, 1.48 \mathrm{M}$ in pentane). The solution was stirred at this temperature for $1 \mathrm{~h}$. To the resulting solution was added a THF $(27 \mathrm{~mL})$ solution of 1,2dibromotetrafluoroethane $(1.1 \mathrm{~mL}, 9.3 \mathrm{mmol})$. The reaction mixture was allowed to warm to room temperature, poured into water, and extracted twice with ethyl acetate. The combined organic layers were dried $\left(\mathrm{Na}_{2} \mathrm{SO}_{4}\right)$ and concentrated in vacuo. The residue was purified by a silica gel flash chromatography (15\% ethyl acetate in hexane) to give $0.808 \mathrm{~g}$ (67\% yield) of (R)-3-bromo-2,2'-bis(methoxy(methoxy))-1,1'-binaphthyl as an amorphous solid: ${ }^{1} \mathrm{H}$ NMR (500 $\left.\mathrm{MHz} ; \mathrm{CDCl}_{3}\right) \delta 2.70(3 \mathrm{H}, \mathrm{s}), 3.19(3 \mathrm{H}, \mathrm{s}), 4.74(1 \mathrm{H}, \mathrm{d}, J=5.4 \mathrm{~Hz}), 4.78(1 \mathrm{H}, \mathrm{d}, J=5.4 \mathrm{~Hz})$, $5.04(1 \mathrm{H}, \mathrm{d}, J=6.9 \mathrm{~Hz}), 5.15(1 \mathrm{H}, \mathrm{d}, J=6.9 \mathrm{~Hz}), 7.16(1 \mathrm{H}, \mathrm{d}, J=8.5 \mathrm{~Hz}), 7.18(1 \mathrm{H}, \mathrm{d}, J=8.9$ $\mathrm{Hz}), 7.23-7.32(2 \mathrm{H}, \mathrm{m}), 7.36(1 \mathrm{H}, \mathrm{t}, J=8.3 \mathrm{~Hz}), 7.42(1 \mathrm{H}, \mathrm{t}, J=8.1 \mathrm{~Hz}), 7.59(1 \mathrm{H}, \mathrm{d}, J=9.1$ Hz), $7.81(1 \mathrm{H}, \mathrm{d}, J=8.2 \mathrm{~Hz}), 7.87(1 \mathrm{H}, \mathrm{d}, J=8.1 \mathrm{~Hz}), 7.97(1 \mathrm{H}, \mathrm{d}, J=9.1 \mathrm{~Hz}), 8.25(1 \mathrm{H}, \mathrm{s})$; ${ }^{13} \mathrm{C}$ NMR $\left(125.8 \mathrm{MHz} ; \mathrm{CDCl}_{3}\right) \delta 55.9,56.5,94.8,99.0,116.3,117.7,120.0,124.1,125.5,125.8$, $126.1,126.5,126.8,127.0,127.75,127.82,129.5,130.1,131.7,132.4,133.1,133.9,149.6$, 152.9 .

A mixture of the bis-MOM derivative $(0.249 \mathrm{~g}, 0.550 \mathrm{mmol})$ and conc. $\mathrm{HCl}(2.5 \mathrm{~mL})$ in ethanol $(15 \mathrm{~mL})$ and dichloromethane $(5 \mathrm{~mL})$ was heated under reflux for $5 \mathrm{~h}$. The mixture was poured into water and extracted twice with $\mathrm{Et}_{2} \mathrm{O}$. The combined organic layers were washed with aqueous $5 \% \mathrm{NaHCO}_{3}$, dried $\left(\mathrm{MgSO}_{4}\right)$, and concentrated in vacuo. The residue was purified by a silica gel flash chromatography (toluene) to give $0.194 \mathrm{~g}$ ( $97 \%$ yield) of $\mathbf{2 b}$ as an amorphous solid: ${ }^{1} \mathrm{H}$ NMR $\left(500 \mathrm{MHz} ; \mathrm{CDCl}_{3}\right) \delta 4.91(1 \mathrm{H}, \mathrm{br} \mathrm{s}), 5.57(1 \mathrm{H}, \mathrm{br} \mathrm{s}), 7.11(1 \mathrm{H}$, $\mathrm{d}, J=8.4 \mathrm{~Hz}), 7.28-7.43(5 \mathrm{H}, \mathrm{m}), 7.83(1 \mathrm{H}, \mathrm{d}, J=8.2 \mathrm{~Hz}), 7.90(1 \mathrm{H}, \mathrm{d}, J=8.0 \mathrm{~Hz}), 7.97(1 \mathrm{H}, \mathrm{d}$, $J=8.9 \mathrm{~Hz}), 8.28(1 \mathrm{H}, \mathrm{s}) ;{ }^{13} \mathrm{C} \mathrm{NMR}\left(125.8 \mathrm{MHz} ; \mathrm{CDCl}_{3}\right) \delta 111.7,112.1,113.2,117.4,124.0$, 124.2 , 124.6, 125.0, 127.40, 127.44, 127.8, 128.4, 129.4, 129.9, 131.4, 132.9, 133.1, 133.3, 148.9, 152.1; FT-IR (KBr disk) 3526, 3483, 3424, 1143, $750 \mathrm{~cm}^{-1}$; HRMS calcd for $\mathrm{C}_{20} \mathrm{H}_{13} \mathrm{O}_{2}{ }^{79} \mathrm{Br}$ : 364.0099, found, 364.0105, calcd for $\mathrm{C}_{20} \mathrm{H}_{13} \mathrm{O}_{2}{ }^{81} \mathrm{Br}$ : 366.0078, found, 366.0098.

(R)-3-Methyl-1,1'-bi-2-naphthol (2c). ${ }^{3}$ To a THF $(89 \mathrm{~mL})$ solution of $(R)-2,2$ 'bis(methoxy(methoxy))-1,1'-binaphthyl $(2.00 \mathrm{~g}, 5.34 \mathrm{mmol})$ at $-78{ }^{\circ} \mathrm{C}$ under nitrogen was added 
$t$-BuLi (5.8 mL, $8.5 \mathrm{mmol}, 1.48 \mathrm{M}$ in pentane). The solution was stirred at this temperature for $3 \mathrm{~h}$. To the resulting solution was added a THF $(25 \mathrm{~mL})$ solution of iodomethane $(0.53 \mathrm{~mL}$, $8.5 \mathrm{mmol}$ ). The reaction mixture was allowed to warm to room temperature, poured into water, and extracted twice with $\mathrm{Et}_{2} \mathrm{O}$. The combined organic layers were dried $\left(\mathrm{MgSO}_{4}\right)$ and concentrated in vacuo. The residue was purified by a silica gel flash chromatography (15\% ethyl acetate in hexane) to give $1.16 \mathrm{~g}(56 \%$ yield $)$ of $(R)-3$-methyl-2,2'bis(methoxy(methoxy))-1,1'-binaphthyl as an amorphous solid: ${ }^{1} \mathrm{H}$ NMR $\left(500 \mathrm{MHz}, \mathrm{CDCl}_{3}\right) \delta$ $2.58(3 \mathrm{H}, \mathrm{s}), 2.90(3 \mathrm{H}, \mathrm{s}), 3.16(3 \mathrm{H}, \mathrm{s}), 4.56(1 \mathrm{H}, \mathrm{d}, J=5.5 \mathrm{~Hz}), 4.64(1 \mathrm{H}, \mathrm{d}, J=5.6 \mathrm{~Hz}), 5.02$ $(1 \mathrm{H}, \mathrm{d}, J=6.9 \mathrm{~Hz}), 5,13(1 \mathrm{H}, \mathrm{d}, J=6.9 \mathrm{~Hz}), 7.14-7.37(6 \mathrm{H}, \mathrm{m}), 7.58(1 \mathrm{H}, \mathrm{d}, J=9.1 \mathrm{~Hz}), 7.80-$ $7.87(2 \mathrm{H}, \mathrm{m}$, including s at 7.80), $7.85(1 \mathrm{H}, \mathrm{d}, J=8.0 \mathrm{~Hz}), 7.96(1 \mathrm{H}, \mathrm{d}, J=9.1 \mathrm{~Hz})$.

A mixture of the bis-MOM derivative $(0.214 \mathrm{~g}, 0.550 \mathrm{mmol})$ and conc. $\mathrm{HCl}(2.5 \mathrm{~mL})$ in ethanol $(15 \mathrm{~mL})$ and dichloromethane $(5 \mathrm{~mL})$ was heated under reflux for $5 \mathrm{~h}$. The mixture was poured into water and extracted twice with $\mathrm{Et}_{2} \mathrm{O}$. The combined organic layers were washed with aqueous $5 \% \mathrm{NaHCO}_{3}$, dried $\left(\mathrm{MgSO}_{4}\right)$, and concentrated in vacuo. The residue was purified by a silica gel flash chromatography (toluene) to give $55.9 \mathrm{mg}$ (34\% yield) of $\mathbf{2 c}^{3}$ as an amorphous solid: ${ }^{1} \mathrm{H}$ NMR $\left(500 \mathrm{MHz} \mathrm{CDCl}_{3}\right) \delta 2.52(3 \mathrm{H}, \mathrm{s}), 5.05(1 \mathrm{H}, \mathrm{br}), 5.10(1 \mathrm{H}$, br s), $7.09(1 \mathrm{H}, \mathrm{d}, J=8.3 \mathrm{~Hz}), 7.15(1 \mathrm{H}, \mathrm{d}, J=8.4 \mathrm{~Hz}), 7.23-7.25(1 \mathrm{H}, \mathrm{m}), 7.30-7.40(4 \mathrm{H}, \mathrm{m})$, $7.82-7.83(2 \mathrm{H}, \mathrm{m}$, including s at 7.82), $7.90(1 \mathrm{H}, \mathrm{d}, J=8.2 \mathrm{~Hz}), 7.98(1 \mathrm{H}, \mathrm{d}, J=8.9 \mathrm{~Hz})$.

(R)-3-Phenyl-1,1'bi-2-naphthol (2d). ${ }^{4} \quad$ To a THF $(267 \mathrm{~mL})$ solution of $(R)-2,2$ 'bis(methoxy(methoxy))-1,1'-binaphthyl $(10.0 \mathrm{~g}, 26.7 \mathrm{mmol})$ at $-78^{\circ} \mathrm{C}$ under nitrogen was added $t$-BuLi (22 mL, $32 \mathrm{mmol}, 1.48 \mathrm{M}$ in pentane). The solution was stirred at this temperature for $3 \mathrm{~h}$. To the resulting solution was added a solution of iodine $(8.12 \mathrm{~g}, 32.0 \mathrm{mmol})$ in THF (90 $\mathrm{mL}$ ). The resulting mixture was stirred for $1 \mathrm{~h}$, allowed to warm to room temperature, and stirred further for $1 \mathrm{~h}$. The reaction mixture was poured into brine $(400 \mathrm{~mL})$ and extracted with ethyl acetate $(3 \times 300 \mathrm{~mL})$. The organic layers were dried $\left(\mathrm{Na}_{2} \mathrm{SO}_{4}\right)$ and concentrated in vacuo. Recrystallization of the crude product from ethyl acetate and hexane gave $(R)$-3-iodo2,2'-bis(methoxy(methoxy))-1,1'-binaphthyl $1^{5}$ (9.70 g, 73 \% yield): mp 123-125 ${ }^{\circ} \mathrm{C}$ (lit. ${ }^{5} 114$ $\left.{ }^{\circ} \mathrm{C}\right) ;{ }^{1} \mathrm{H}$ NMR $\left(500 \mathrm{MHz}, \mathrm{CDCl}_{3}\right) \delta 2.79(\mathrm{~s}, 3 \mathrm{H}), 3.27$ (s, 3H), $4.76(\mathrm{~d}, J=5.3 \mathrm{~Hz}, 1 \mathrm{H}), 4.81(\mathrm{~d}, J$ $=5.2 \mathrm{~Hz}, 1 \mathrm{H}), 5.12(\mathrm{~d}, J=7.0 \mathrm{~Hz}, 1 \mathrm{H}), 5.21(\mathrm{~d}, J=7.0 \mathrm{~Hz}, 1 \mathrm{H}), 7.21-7.24(\mathrm{~m}, 2 \mathrm{H}), 7.31-7.37$ $(\mathrm{m}, 2 \mathrm{H}), 7.42-7.48(\mathrm{~m}, 2 \mathrm{H}), 7.65(\mathrm{~d}, J=9.1 \mathrm{~Hz}, 1 \mathrm{H}), 7.85(\mathrm{~d}, J=8.2 \mathrm{~Hz}, 1 \mathrm{H}), 7.93(\mathrm{~d}, J=8.1$ $\mathrm{Hz}, 1 \mathrm{H}), 8.04(\mathrm{~d}, J=9.1 \mathrm{~Hz}, 1 \mathrm{H}), 8.59(\mathrm{~s}, 1 \mathrm{H}) ;{ }^{13} \mathrm{C} \mathrm{NMR}\left(126 \mathrm{MHz}, \mathrm{CDCl}_{3}\right) \delta 56.0,56.8,92.9$, $94.8,99.1,116.2,120.1,124.2,125.4,125.6,126.1,126.4,126.7,126.78,126.81,127.8,129.5$, $130.1,132.4,133.8,139.3,139.4,151.6,152.9$. 
A mixture of (R)-3-iodo-2,2'-bis(methoxy(methoxy))-1,1'-binaphthyl (0.500 g, $1.00 \mathrm{mmol})$, phenylboronic acid $(0.183 \mathrm{~g}, 1.50 \mathrm{mmol})$, and $\mathrm{Pd}\left(\mathrm{PPh}_{3}\right)_{4}(57.8 \mathrm{mg}, 0.050 \mathrm{mmol})$ in aqueous $2 \mathrm{M}$ $\mathrm{Na}_{2} \mathrm{CO}_{3}(2 \mathrm{~mL})$ and 1,4-dioxane $(14.5 \mathrm{~mL})$ was heated under reflux for $18 \mathrm{~h}$ under argon atmosphere. The reaction mixture was poured into water and extracted twice with ethyl acetate. The combined organic layers were dried $\left(\mathrm{Na}_{2} \mathrm{SO}_{4}\right)$ and concentrated in vacuo. The residue was purified by flash column chromatography (10\% ethyl acetate in toluene) to give $0.405 \mathrm{~g}$ (90\% yield) of (R)-3-phenyl-2,2'-bis(methoxy(methoxy))-1,1'-binaphthyl as an amorphous solid; ${ }^{1} \mathrm{H}$ NMR (500 MHz; $\left.\mathrm{CDCl}_{3}\right) \delta 2.29(3 \mathrm{H}, \mathrm{s}), 3.23(3 \mathrm{H}, \mathrm{s}), 4.30(1 \mathrm{H}, \mathrm{d}, J=5.9 \mathrm{~Hz}), 4.36(1 \mathrm{H}, \mathrm{d}, J=$ $5.9 \mathrm{~Hz}), 5.08(1 \mathrm{H}, \mathrm{d}, J=6.9 \mathrm{~Hz}), 5.19(1 \mathrm{H}, \mathrm{d}, J=6.9 \mathrm{~Hz}), 7.22-7.30(4 \mathrm{H}, \mathrm{m}), 7.35-7.47(5 \mathrm{H}$, m), $7.61(1 \mathrm{H}, \mathrm{d}, J=9.1 \mathrm{~Hz}), 7.72-7.74(2 \mathrm{H}, \mathrm{m}), 7.87(1 \mathrm{H}, \mathrm{d}, J=8.1 \mathrm{~Hz}), 7.91(1 \mathrm{H}, \mathrm{d}, J=8.3$ $\mathrm{Hz})$, 7.95-7.97 (2H, m, including s at 7.96).

A mixture of the bis-MOM derivative $(0.400 \mathrm{~g}, 0.888 \mathrm{mmol})$ and conc. $\mathrm{HCl}(4.5 \mathrm{~mL})$ in ethanol $(27 \mathrm{~mL})$ and dichloromethane $(9 \mathrm{~mL})$ was heated under reflux for $3 \mathrm{~h}$. The mixture was poured into water and extracted twice with diethyl ether. The combined organic layers were washed with aqueous $5 \% \mathrm{NaHCO}_{3}$, dried $\left(\mathrm{MgSO}_{4}\right)$, and concentrated in vacuo. The residue was purified by a silica gel flash chromatography (toluene) to give $0.284 \mathrm{~g}$ ( $88 \%$ yield) of $\mathbf{2} \mathbf{d}^{4}$ as an amorphous solid: ${ }^{1} \mathrm{H}$ NMR $\left(500 \mathrm{MHz} ; \mathrm{CDCl}_{3}\right) \delta 5.02(1 \mathrm{H}$, br s), $5.29(1 \mathrm{H}$, br s), 7.15-7.26 (2H, m), 7.32-7.33 (2H, m), 7.37-7.43 (4H, m), 7.49-7.52 (2H, m), 7.72-7.75 (2H, m), $7.91(1 \mathrm{H}, \mathrm{d}, J=7.9 \mathrm{~Hz}), 7.93(1 \mathrm{H}, \mathrm{d}, J=8.1 \mathrm{~Hz}), 7.99(1 \mathrm{H}, \mathrm{d}, J=8.9 \mathrm{~Hz}), 8.03(1 \mathrm{H}, \mathrm{s})$.

(R)-3-(3,5-Dimethylphenyl)-1,1'bi-2-naphthol (2e). A mixture of (R)-2,2'bis(methoxy(methoxy))-3-ioodo-1,1'-binaphthyl (0.500 g, $1.00 \mathrm{mmol})$, 3,5-dimethylphenylboronic acid $(0.225 \mathrm{~g}, 1.50 \mathrm{mmol})$, and $\mathrm{Pd}\left(\mathrm{PPh}_{3}\right)_{4}(57.8 \mathrm{mg}, 0.050 \mathrm{mmol})$ in aqueous $2 \mathrm{M}$ $\mathrm{Na}_{2} \mathrm{CO}_{3}(2 \mathrm{~mL})$ and 1,4-dioxane $(14.5 \mathrm{~mL})$ was heated under reflux for $18 \mathrm{~h}$ under argon atmosphere. The reaction mixture was poured into water and extracted twice with ethyl acetate. The combined organic layers were dried $\left(\mathrm{Na}_{2} \mathrm{SO}_{4}\right)$ and concentrated. The residue was dissolved in a mixture of conc. $\mathrm{HCl}(3 \mathrm{~mL})$, ethanol $(18 \mathrm{~mL})$, and dichloromethane $(6 \mathrm{~mL})$. After being heated under reflux for $4 \mathrm{~h}$, the reaction mixture was poured into water and extracted twice with diethyl ether. The combined organic layers were washed with aqueous $5 \% \mathrm{NaHCO}_{3}$, dried $\left(\mathrm{MgSO}_{4}\right)$, and concentrated in vacuo. The residue was purified by a silica gel flash chromatography (3\% ethyl acetate in toluene) to give $0.308 \mathrm{~g}$ (79\% yield) of $\mathbf{2 e}$ as an amorphous solid: ${ }^{1} \mathrm{H}$ NMR $\left(500 \mathrm{MHz} ; \mathrm{CDCl}_{3}\right) \delta 2.42(6 \mathrm{H}, \mathrm{m}), 5.11(1 \mathrm{H}, \mathrm{br} \mathrm{s}), 5.36(1 \mathrm{H}, \mathrm{br} \mathrm{s})$, $7.08(1 \mathrm{H}$, br s), $7.17(1 \mathrm{H}, \mathrm{d}, J=8.4 \mathrm{~Hz}), 7.24(1 \mathrm{H}, \mathrm{d}, J=8.5 \mathrm{~Hz}), 7.28-7.43(7 \mathrm{H}, \mathrm{m}$, including br s $(2 \mathrm{H})$ at 7.34 and $\mathrm{d}(2 \mathrm{H}, J=8.9 \mathrm{~Hz})$ at 7.40$), 7.90(1 \mathrm{H}, \mathrm{d}, J=8.0 \mathrm{~Hz}), 7.92(1 \mathrm{H}, \mathrm{d}, J=8.5$ 
$\mathrm{Hz}), 7.98(1 \mathrm{H}, J=8.9 \mathrm{~Hz}), 8.01(1 \mathrm{H}, \mathrm{s}) ;{ }^{13} \mathrm{C} \mathrm{NMR}\left(125.8 \mathrm{MHz} ; \mathrm{CDCl}_{3}\right) \delta 21.4,111.7,111.9$, $117.7,123.9,124.2$, 124.3, 124.4, 127.3 (3C), 128.36, 128.38, 129.4, 129.6, 130.9, 131.1, 131.2, 133.0 (2C), 133.4, 137.1, 138.3, 150.2, 152.5; FT-IR (KBr disk) 3472, 3403, 1143, 823, $752 \mathrm{~cm}^{-}$ ; HRMS calcd for $\mathrm{C}_{28} \mathrm{H}_{22} \mathrm{O}_{2}: 390.1620$, found, 390.1613.

(R)-3-(3,5-Diphenylphenyl)-1,1'bi-2-naphthol (2f). A mixture of $(R)-2,2$ 'bis(methoxy(methoxy))-3-ioodo-1,1'-binaphthyl (0.240 g, $0.48 \mathrm{mmol})$, 2,4,6-tris-( $m$-terphenyl5-yl)boroxine $(0.146 \mathrm{~g}, 0.19 \mathrm{mmol})$, and $\mathrm{Pd}\left(\mathrm{PPh}_{3}\right)_{4}(27.7 \mathrm{mg}, 0.024 \mathrm{mmol})$ in aqueous $2 \mathrm{M}$ $\mathrm{Na}_{2} \mathrm{CO}_{3}(1 \mathrm{~mL})$ and 1,4-dioxane $(7 \mathrm{~mL})$ was heated under reflux for $18 \mathrm{~h}$ under argon atmosphere. The reaction mixture was poured into water and extracted twice with ethyl acetate. The combined organic layers were dried $\left(\mathrm{Na}_{2} \mathrm{SO}_{4}\right)$ and concentrated. The residue was purified by a silica gel flash chromatography (ethyl acetate, toluene, and hexane; 5:45:50) to give $0.259 \mathrm{~g}$ (90\% yield) of $(R)-2,2$ '-bis(methoxy(methoxy))-3-(3,5-diphenylphenyl)-1,1'binaphthyl as an amorphous solid: ${ }^{1} \mathrm{H}$ NMR $\left(500 \mathrm{MHz} ; \mathrm{CDCl}_{3}\right) \delta 2.35(3 \mathrm{H}, \mathrm{s}), 3.27(3 \mathrm{H}, \mathrm{s})$, $4.40(1 \mathrm{H}, \mathrm{d}, J=6.0 \mathrm{~Hz}), 4.48(1 \mathrm{H}, \mathrm{d}, J=6.0 \mathrm{~Hz}), 5.12(1 \mathrm{H}, \mathrm{d}, J=6.9 \mathrm{~Hz}), 5.19(1 \mathrm{H}, \mathrm{d}, J=6.9$ $\mathrm{Hz}), 7.22-7.45(8 \mathrm{H}, \mathrm{m}), 7.48(4 \mathrm{H}$, br t, $J=c a .8 \mathrm{~Hz}), 7.62(1 \mathrm{H}, \mathrm{d}, J=9.1 \mathrm{~Hz}), 7.72(4 \mathrm{H}, \mathrm{br} \mathrm{d}, J$ $=c a .8 \mathrm{~Hz}), 7.82(1 \mathrm{H}, \mathrm{t}, J=0.8 \mathrm{~Hz}), 7.88(1 \mathrm{H}, \mathrm{d}, J=8.1 \mathrm{~Hz}), 7.93(1 \mathrm{H}, \mathrm{d}, J=8.2 \mathrm{~Hz}), 7.951$ $(1 \mathrm{H}, \mathrm{s}), 7.954(1 \mathrm{H}, \mathrm{s}), 7.97(1 \mathrm{H}, \mathrm{d}, J=9.1 \mathrm{~Hz}), 8.08(1 \mathrm{H}, \mathrm{s})$.

A mixture of the bis-MOM derivative $(0.259 \mathrm{~g}, 0.43 \mathrm{mmol})$ and conc. $\mathrm{HCl}(3.5 \mathrm{~mL})$ in ethanol $(21 \mathrm{~mL})$, and dichloromethane $(7 \mathrm{~mL})$ was heated under reflux for $5 \mathrm{~h}$. The reaction mixture was poured into water and extracted twice with diethyl ether. The combined organic layers were washed with aqueous $5 \% \mathrm{NaHCO}_{3}$, dried $\left(\mathrm{MgSO}_{4}\right)$, and concentrated in vacuo. The residue was purified by a silica gel flash chromatography (10\% ethyl acetate in hexane) to give $0.208 \mathrm{~g}$ (94\% yield) of $\mathbf{2 f}$ as an amorphous solid: ${ }^{1} \mathrm{H} \mathrm{NMR}\left(500 \mathrm{MHz}, \mathrm{CDCl}_{3}\right) \delta 5.15(1 \mathrm{H}$, br s), $5.39(1 \mathrm{H}$, br s), $7.18(1 \mathrm{H}, \mathrm{d}, J=8.4 \mathrm{~Hz}), 7.27(1 \mathrm{H}, \mathrm{d}, J=8.6 \mathrm{~Hz}), 7.31-7.44(7 \mathrm{H}, \mathrm{m}), 7.48$ $(4 \mathrm{H}$, br d, $J=c a .8 \mathrm{~Hz}), 7.72(4 \mathrm{H}, \mathrm{br} \mathrm{d}, J=c a .8 \mathrm{~Hz}), 7.86(1 \mathrm{H}, \mathrm{t}, J=0.8 \mathrm{~Hz}), 7.91(1 \mathrm{H}, \mathrm{d}, J=$ $7.7 \mathrm{~Hz}), 7.94-7.96(3 \mathrm{H}, \mathrm{m}$, including s at 7.960 and 7.963$), 8.00(1 \mathrm{H}, \mathrm{d}, J=8.9 \mathrm{~Hz}), 8.16(1 \mathrm{H}$, s); ${ }^{13} \mathrm{C} \mathrm{NMR}\left(125.8 \mathrm{MHz} ; \mathrm{CDCl}_{3}\right) \delta 111.2,111.9,117.8,124.0,124.2,124.3,124.5,125.6$, 127.4 (2C), 127.52, 127.54, 128.4, 128.5, 128.8 (2C), 129.5, 130.4, 131.5, 131.6, 133.0, 133.4 (2C), 138.3, 141.0, 142.1, 150.4, 152.7; FT-IR (KBr disk) 3508, 3399, 1138, 758, 724, $698 \mathrm{~cm}^{-1}$; HRMS calcd for $\mathrm{C}_{38} \mathrm{H}_{26} \mathrm{O}_{2}$ : 514.1933, found, 514.1934.

(R)-3-(2,6-Dimethylphenyl)-1,1'bi-2-naphthol (2g). ${ }^{6} \quad$ To a THF $(50 \mathrm{~mL})$ solution of $(R)$ 2,2'-bis(methoxy(methoxy))-1,1'-binaphthyl at $-78{ }^{\circ} \mathrm{C}$ under argon atmosphere was added $t$ BuLi (4.03 mL, $6.0 \mathrm{mmol}, 1.48 \mathrm{M}$ in pentane). The solution was stirred at the same 
temperature for $3 \mathrm{~h}$. To the resulting solution at $-78{ }^{\circ} \mathrm{C}$ was added $\mathrm{B}(\mathrm{OMe})_{3}(4.7 \mathrm{~mL}, 42$ mmol). The resulting mixture was allowed to warm to room temperature and stirred for $15 \mathrm{~h}$. After the addition of $1 \mathrm{M} \mathrm{HCl}(50 \mathrm{~mL})$ at $0{ }^{\circ} \mathrm{C}$, the reaction mixture was stirred further for $2 \mathrm{~h}$, poured into water, and extracted twice with diethyl ether. The combined organic layers were washed with $1 \mathrm{~N} \mathrm{HCl}$ and brine, dried $\left(\mathrm{MgSO}_{4}\right)$, and concentrated in vacuo. The residue was purified by a silica gel flash chromatography (10\% ethyl acetate in hexane) to give $1.43 \mathrm{~g}$ (68\% yield) of (R)-2,2'-bis(methoxy(methoxy))-1,1'-binaphthyl-3-boronic acid as an amorphous solid.

In a flask equipped with a reflux condenser were placed $(R)-2,2$ '-bis(methoxy(methoxy))1,1'-binaphthyl-3-boronic acid $(0.335 \mathrm{~g}, 0.800 \mathrm{mmol}), \mathrm{Ba}(\mathrm{OH})_{2} \cdot 8 \mathrm{H}_{2} \mathrm{O}(0.379 \mathrm{~g}, 1.20 \mathrm{mmol})$, and $\mathrm{Pd}\left(\mathrm{PPh}_{3}\right)_{4}(46.2 \mathrm{mg}, 0.040 \mathrm{mmol})$, and the flask was evacuated and filled with argon gas. 1,4-Dioxane (12 mL), $\mathrm{H}_{2} \mathrm{O}(4 \mathrm{~mL})$, and 2-bromo- $m$-xylene $(0.160 \mathrm{~mL}, 1.20 \mathrm{mmol})$ were added. After being heated under reflux for $24 \mathrm{~h}$, the reaction mixture was poured into water and extracted twice with ethyl acetate. The combined organic layers were dried $\left(\mathrm{Na}_{2} \mathrm{SO}_{4}\right)$ and concentrated in vacuo. The residue was purified by a silica gel flash chromatography $(10 \%$ ethyl acetate in hexane) to give $92.7 \mathrm{mg}$ (24\% yield) of $(R)-2,2^{\prime}$-bis(methoxy(methoxy))-3-(2,6diphenylphenyl)-1,1'-binaphthyl: ${ }^{1} \mathrm{H}$ NMR (500 MHz; $\left.\mathrm{CDCl}_{3}\right) \delta 2.22(3 \mathrm{H}, \mathrm{s}), 2.25(3 \mathrm{H}, \mathrm{s})$, $2.27(3 \mathrm{H}, \mathrm{s}), 3.21(3 \mathrm{H}, \mathrm{s}), 4.22(1 \mathrm{H}, \mathrm{d}, J=5.7 \mathrm{~Hz}), 4.29(1 \mathrm{H}, \mathrm{d}, J=5.7 \mathrm{~Hz}), 5.16(1 \mathrm{H}, \mathrm{d}, J=6.9$ Hz), $5.13(1 \mathrm{H}, \mathrm{d}, J=6.9), 7.13-7.18(3 \mathrm{H}, \mathrm{m}), 7,24-7.28(5 \mathrm{H}, \mathrm{m}), 7.34-7.36(1 \mathrm{H}, \mathrm{m}), 7.40-7.42$ $(1 \mathrm{H}, \mathrm{m}), 7.59(1 \mathrm{H}, \mathrm{d}, J=9.1 \mathrm{~Hz}), 7.74(1 \mathrm{H}, \mathrm{s}), 7.86(1 \mathrm{H}, \mathrm{d}, J=8.0 \mathrm{~Hz}), 7.88(1 \mathrm{H}, \mathrm{d}, J=7.7 \mathrm{~Hz})$, $7.95(1 \mathrm{H}, \mathrm{d}, J=9.1 \mathrm{~Hz})$.

A mixture of the bis-MOM derivative $(84.3 \mathrm{mg}, 0.18 \mathrm{mmol})$ and conc. $\mathrm{HCl}(1 \mathrm{~mL})$ in ethanol $(6 \mathrm{~mL})$, and dichloromethane $(2 \mathrm{~mL})$ was heated under reflux for $3 \mathrm{~h}$. The reaction mixture was poured into water and extracted twice with diethyl ether. The combined organic layers were washed with aqueous $5 \% \mathrm{NaHCO}_{3}$, dried $\left(\mathrm{MgSO}_{4}\right)$, and concentrated in vacuo. The residue was purified by a silica gel flash chromatography (15\% ethyl acetate in hexane) to give $67.9 \mathrm{mg}$ (97\% yield) of $\mathbf{2} \mathbf{g}^{6}$ as an amorphous solid: ${ }^{1} \mathrm{H}$ NMR $\left(500 \mathrm{MHz} ; \mathrm{CDCl}_{3}\right) \delta 2.17$ $(3 \mathrm{H}, \mathrm{s}), 2,18(3 \mathrm{H}, \mathrm{s}), 4.97(1 \mathrm{H}, \mathrm{br}), 4.98(1 \mathrm{H}, \mathrm{br} \mathrm{s}), 7.20-7.25(5 \mathrm{H}, \mathrm{m}), 7.31-7.41(5 \mathrm{H}, \mathrm{m})$, $7.80(1 \mathrm{H}, \mathrm{s}), 7.90(2 \mathrm{H}, \mathrm{d}, J=8.1 \mathrm{~Hz}), 7.97(1 \mathrm{H}, \mathrm{d}, J=8.9 \mathrm{~Hz})$.

Asymmetric Ethylation of 1-Naphthaldehyde Catalyzed by BINOL Derivative $2 \mathrm{f}$ (A Representative Procedure; Table 3, entry 7). To a solution of $\mathbf{2 f}(5.1 \mathrm{mg}, 0.01 \mathrm{mmol})$ in $\mathrm{CH}_{2} \mathrm{Cl}_{2}(8 \mathrm{~mL})$ at room temperature under argon atmosphere was added titanium tetraisopropoxide $(0.413 \mathrm{~mL}, 1.4 \mathrm{mmol})$. The resulting solution was stirred for $10 \mathrm{~min}$ at room 
temperature. To this at $0{ }^{\circ} \mathrm{C}$ was added diethylzinc $(1 \mathrm{M}$ in hexane, $3 \mathrm{~mL}, 3.0 \mathrm{mmol})$ and stirring was continued for $10 \mathrm{~min}$. To the resulting mixture was added 1-naphthaldehyde $(0.156 \mathrm{~g}, 1.0 \mathrm{mmol})$ at $0{ }^{\circ} \mathrm{C}$. After being stirred for $2 \mathrm{~h}$, the reaction mixture was quenched by the addition of aqueous $1 \mathrm{~N} \mathrm{HCl}$ and extracted twice with ethyl acetate. The organic layers were washed with aqueous $5 \% \mathrm{NaHCO}_{3}$, dried $\left(\mathrm{Na}_{2} \mathrm{SO}_{4}\right)$, and concentrated in vacuo. Kugelrohr distillation of the residue at reduced pressure $\left(160^{\circ} \mathrm{C}, 2 \mathrm{~mm} \mathrm{Hg}\right)$ afforded $0.177 \mathrm{~g}$ (95\% yield) of $(R)-1-(1-n a p h t h y l)-1-p r o p a n o l ~(95 \%$ ee). The ee values was determined by HPLC analysis using a Chiralcel OD column $(0.8 \mathrm{~mL} / \mathrm{min}, 10 \% i-\mathrm{PrOH}$ in hexane); retention times: $11.0 \mathrm{~min}$ (minor $S$-enantiomer) and $19.0 \mathrm{~min}$ (major $R$-enantiomer). The absolute structure of the product was determined by comparing the retention time with that of an authentic sample prepared by asymmetric ethylation using $(R)$-BINOL as a ligand. ${ }^{7}$

Ee Determination of Products. The ee values of the asymmetric alkylation products were determined by chiral stationary phase HPLC. 1-Phenyl-1-propanol (Table 2, entry 2) (Chiralcel OD column, $1.0 \mathrm{~mL} / \mathrm{min}, 3 \% i$-PrOH in hexane); retention times: $11.0 \mathrm{~min}$ (major $R$ enantiomer) and $13.0 \mathrm{~min}$ (minor $S$-enantiomer). 1-(p-Methylphenyl)-1-propanol (Table 3, entry 1) (Chiralcel OD column, $1.0 \mathrm{~mL} / \mathrm{min}, 0.1 \% \mathrm{i}-\mathrm{PrOH}$ in hexane); retention times: $65.5 \mathrm{~min}$ (major $R$-enantiomer) and $80.1 \mathrm{~min}$ (minor $S$-enantiomer). 1-(m-Methoxyphenyl)-1-propanol (Table 3, entry 3) (Chiralcel OD column, $1.0 \mathrm{~mL} / \mathrm{min}, 1 \% i$-PrOH in hexane); retention times: $46.7 \mathrm{~min}$ (major $R$-enantiomer) and $57.8 \mathrm{~min}$ (minor $S$-enantiomer). 1-(o-Chlorophenyl)-1propanol (Table 3, entry 5) (Chiralcel OB column, $1.0 \mathrm{~mL} / \mathrm{min}, 1 \% i-\mathrm{PrOH}$ in hexane) ; retention times: $9.8 \mathrm{~min}$ (minor $S$-enantiomer) and $11.4 \mathrm{~min}$ (major $R$-enantiomer). 1-(1Naphthyl)-1-propanol (Table 3, entry 7) (Chiralcel OD column, $0.8 \mathrm{~mL} / \mathrm{min}, 10 \% i$-PrOH in hexane); retention times: $11.0 \mathrm{~min}$ (minor $S$-enantiomer) and $19.0 \mathrm{~min}$ (major $R$-enantiomer). 1-(2-Naphthyl)-1-propanol (Table 3, entry 9) (Chiralcel OD column, $0.8 \mathrm{~mL} / \mathrm{min}, 10 \% i$-PrOH in hexane); retention times: $12.0 \mathrm{~min}$ (minor $S$-enantiomer) and $13.5 \mathrm{~min}$ (major $R$-enantiomer). 1-Phenyl-3-pentanol (Table 3, entry 11) (Chiralcel OD column, $1.0 \mathrm{~mL} / \mathrm{min}, 2 \% i$-PrOH in hexane); retention times: $16.4 \mathrm{~min}$ (major $R$-enantiomer) and $27.3 \mathrm{~min}$ (minor $S$-enantiomer). (E)-1-Phenylpent-1-en-3-ol (Table 3, entry 12) (Chiralcel OD column, $1.0 \mathrm{~mL} / \mathrm{min}, 3 \% i$-PrOH in hexane); retention times: $18.5 \mathrm{~min}$ (major $R$-enantiomer) and $32.3 \mathrm{~min}$ (minor $S$-enantiomer). 


\section{References}

(1) Harada, T.; Kanda, K.; Hiraoka, Y.; Marutani, Y; Nakatsugawa, M. Tetrahedron: Asymmetry 2004, 15, 3879.

(2) Lingenfelter, D. S.; Helgeson, R. C.; Cram, D. J. J. Org. Chem. 1981, 46, 393.

(3) Dennis, M. R.; Woodward, S. J. Chem. Soc., Perkin Trans. 1 1998, 1081.

(4) Ishihara, K.; Kurihara, H.; Matsumoto, M.; Yamamoto, H. J. Am. Chem. Soc. 1998, 120, 6920.

(5) Lutzen, A.; Hapke, M.; Meyer, S. Synthesis 2002, 2289.

(6) Simonsen, K. B.; Gothelf, K.V.; Jorgensen, K. A. J. Org. Chem. 1998, 63, 7536.

(7) F.-Y. Zhang, C.-W. Yip, R. Cao, and A. S. C. Chan, Tetrahedron: Asymmetry, 1997, 8, 585. 

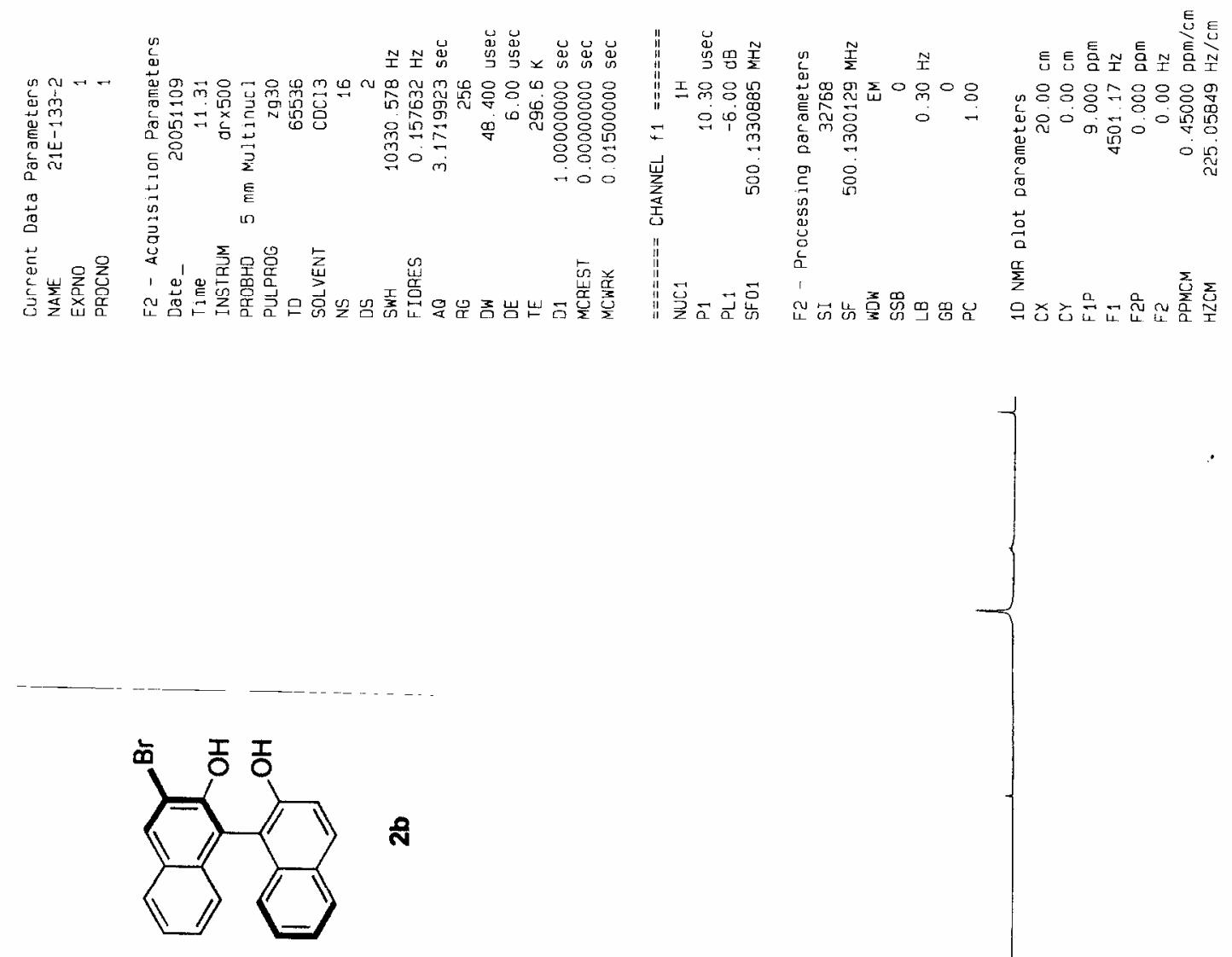

a 


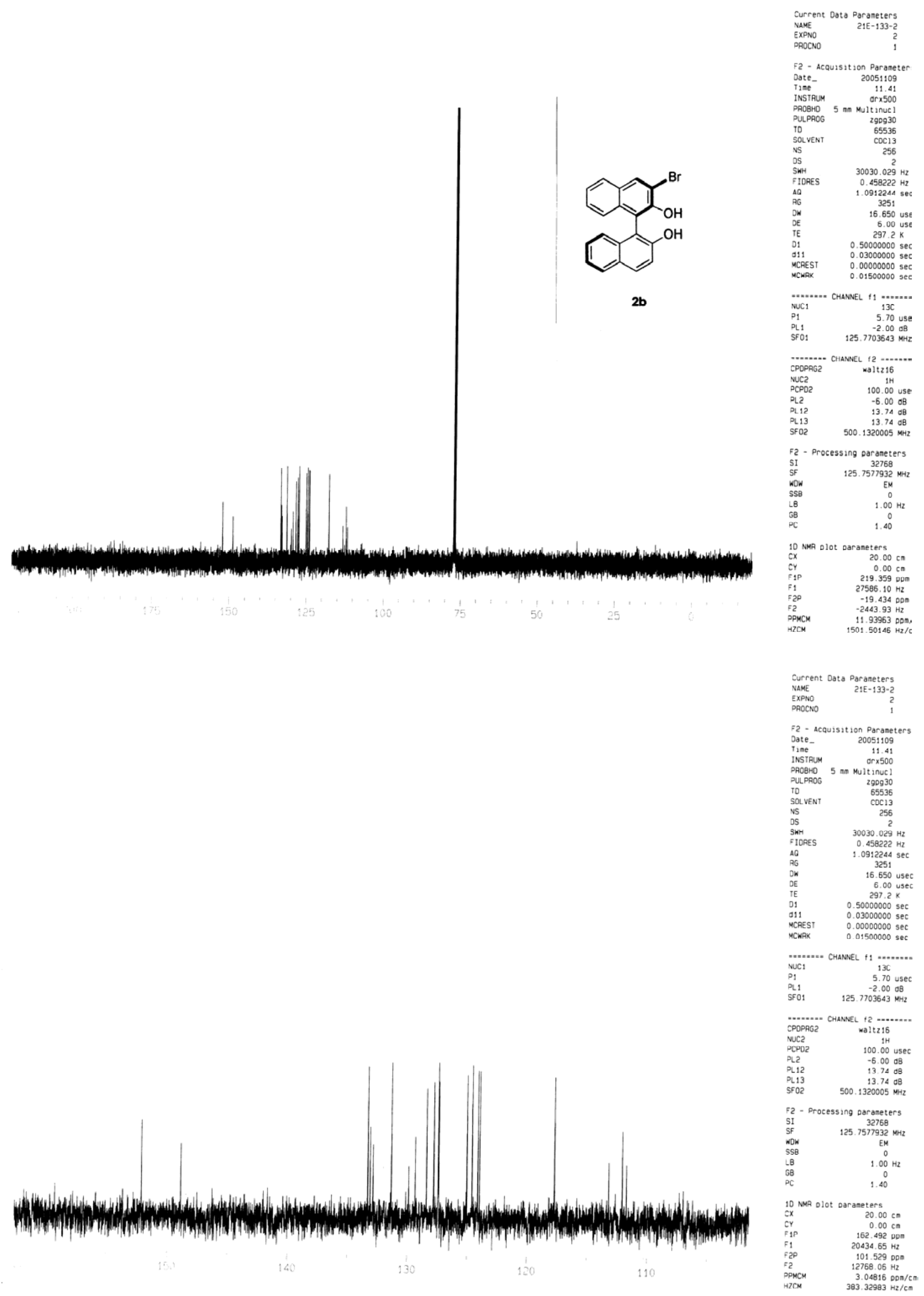



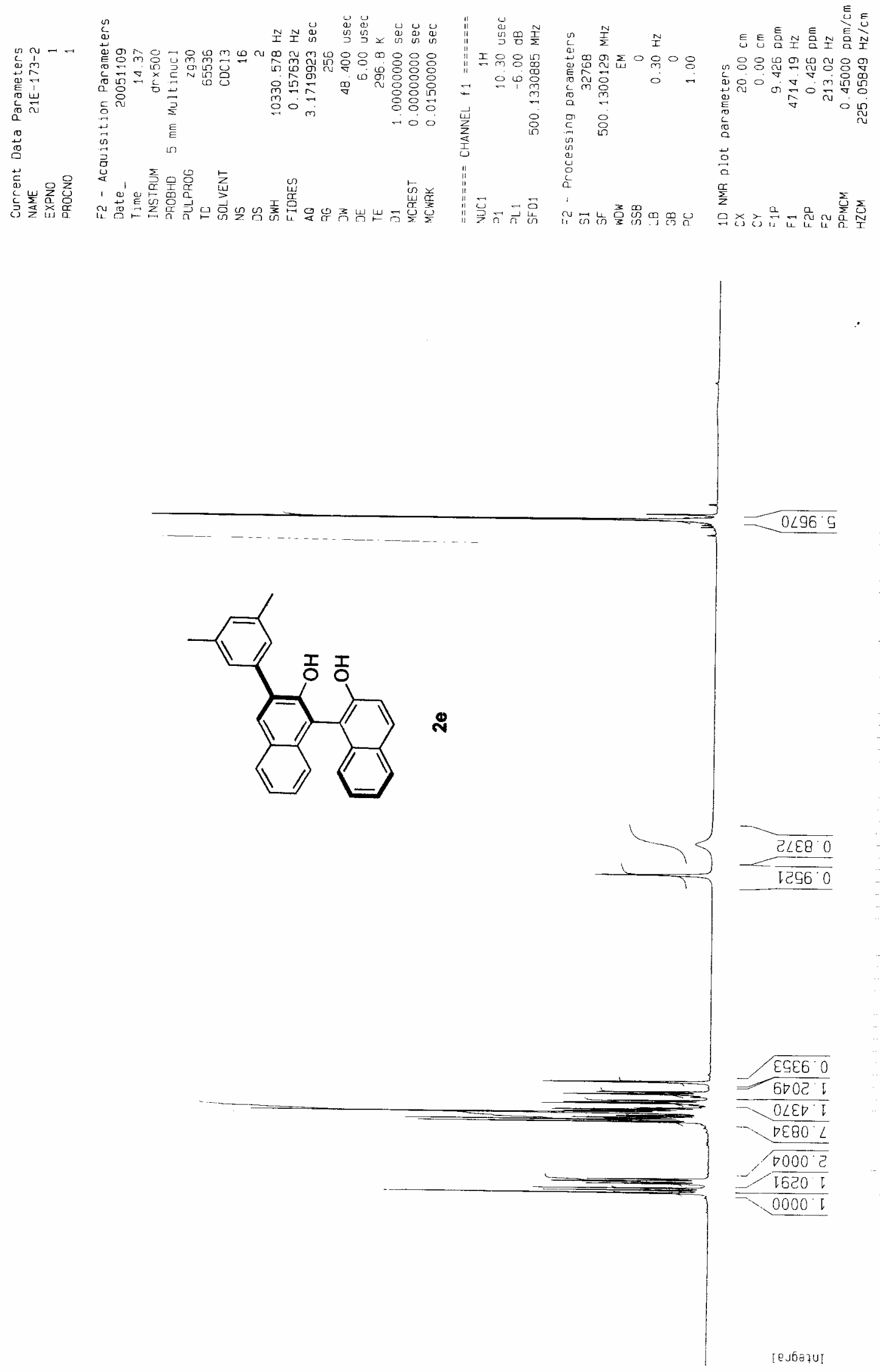


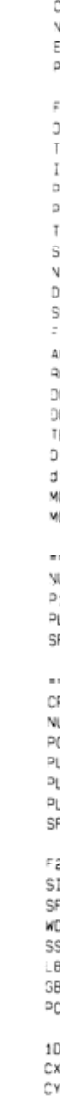

$\begin{array}{lr}\text { Current Data Parameters } \\ \text { VAME } & 21 E-173-2 \\ \text { EXPNO } & \text { ? } \\ \text { DAOCNO } & 1\end{array}$

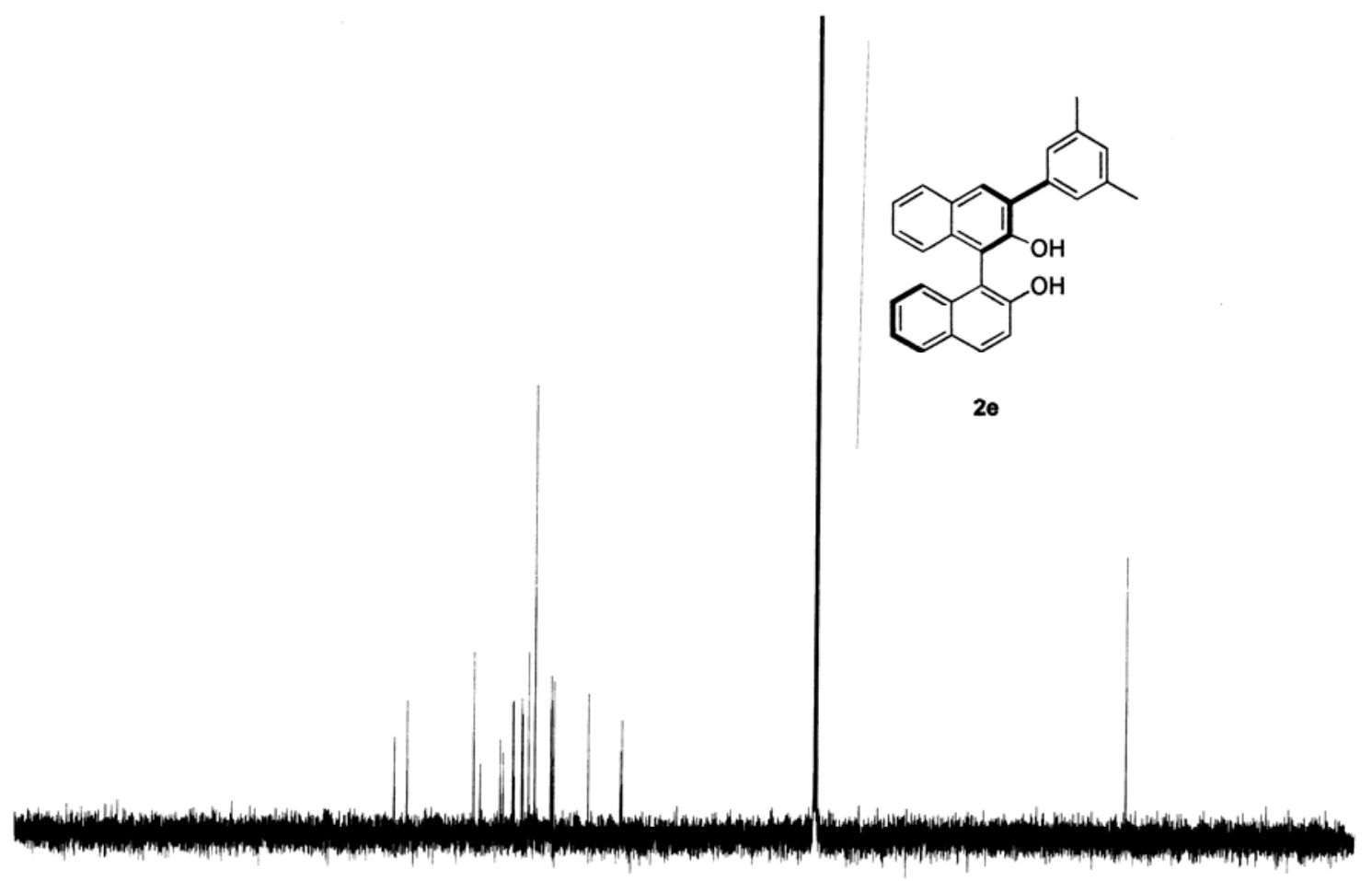

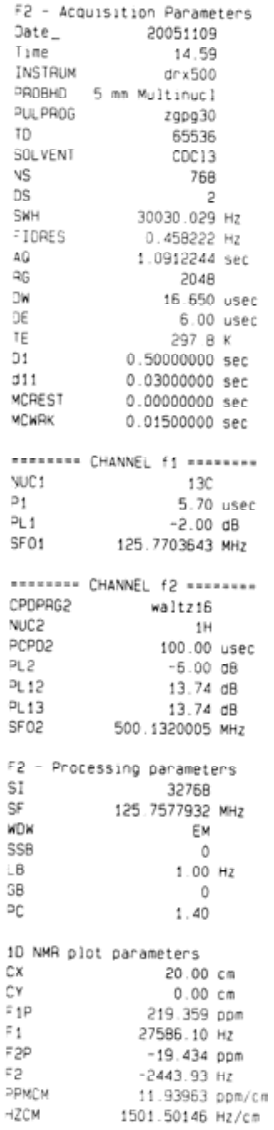

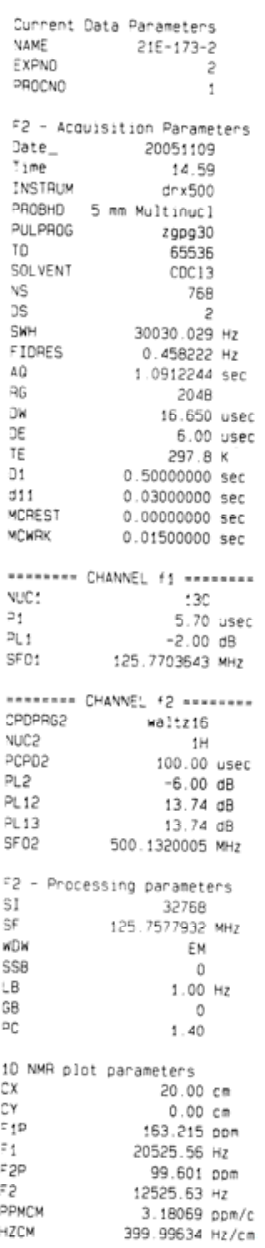



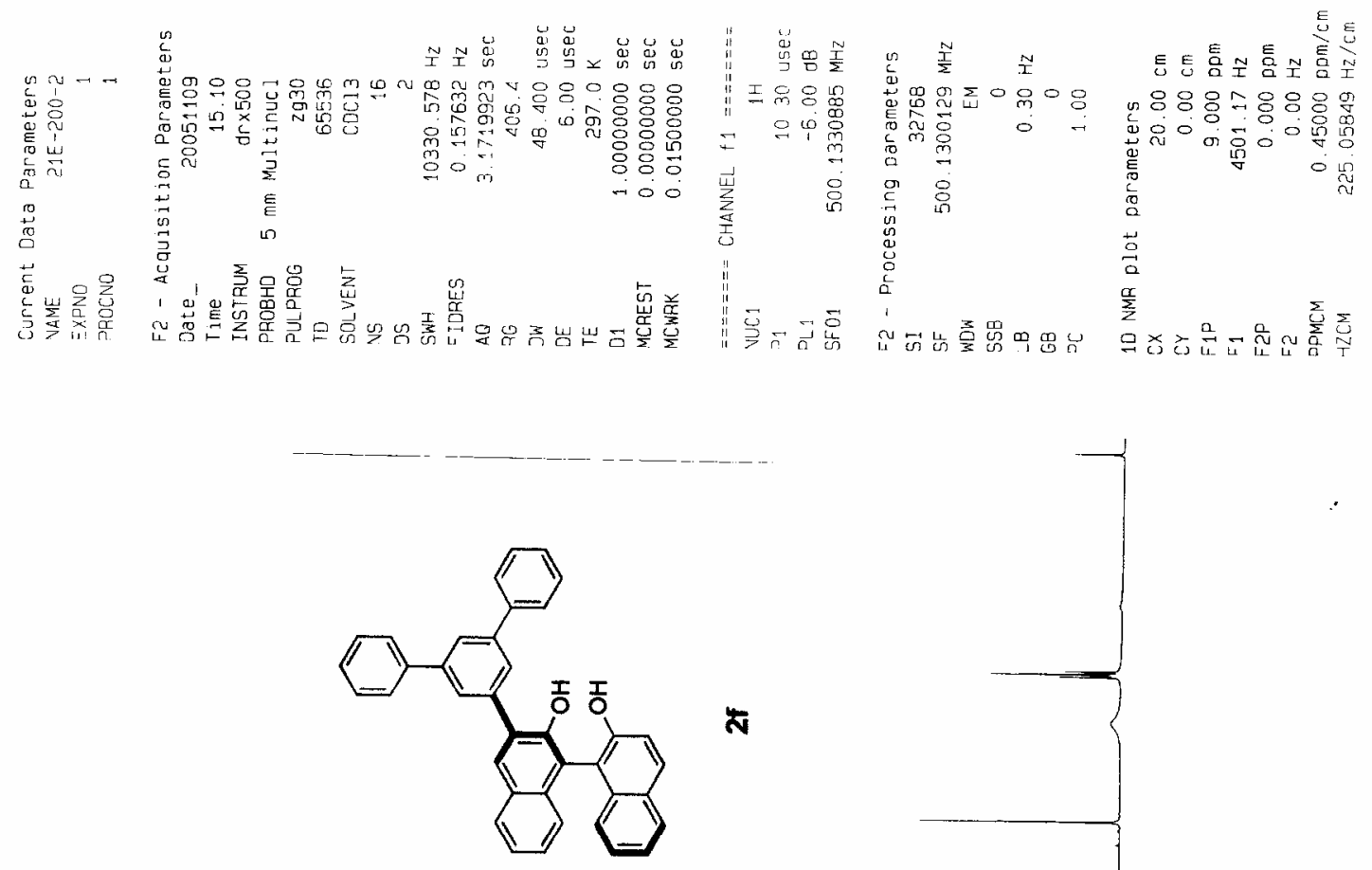

0
$\stackrel{1}{1}$
을
10
0

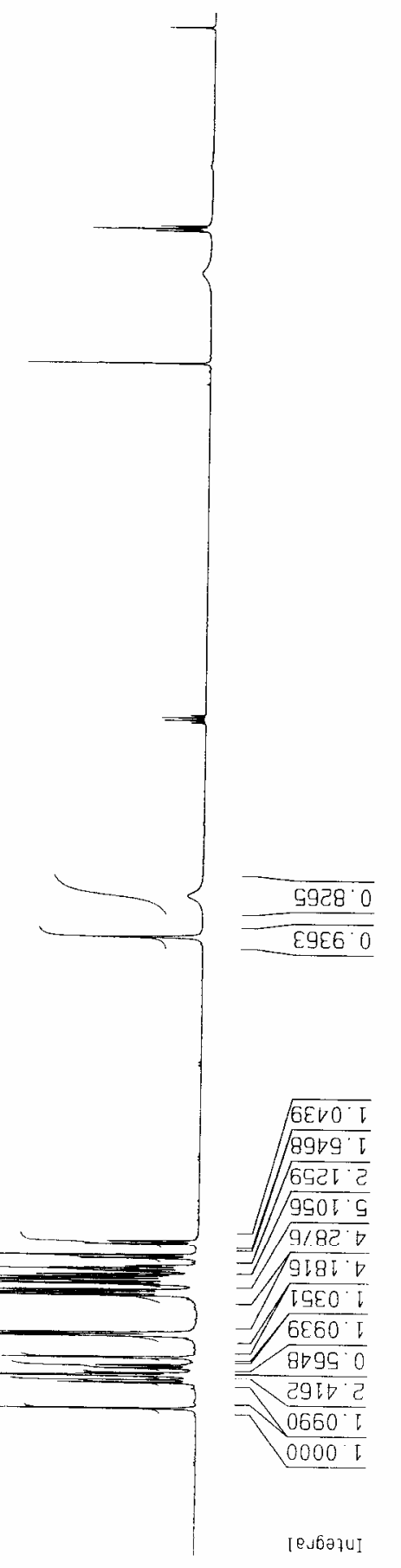


F2 - Acquisition Paraneters

Date _- Acqust 20051210

Date- 20051210

9.11
INSTRUM Or $\times 500$

PAOBHO 5 mim Mult inucl 1
PULPROG
290930

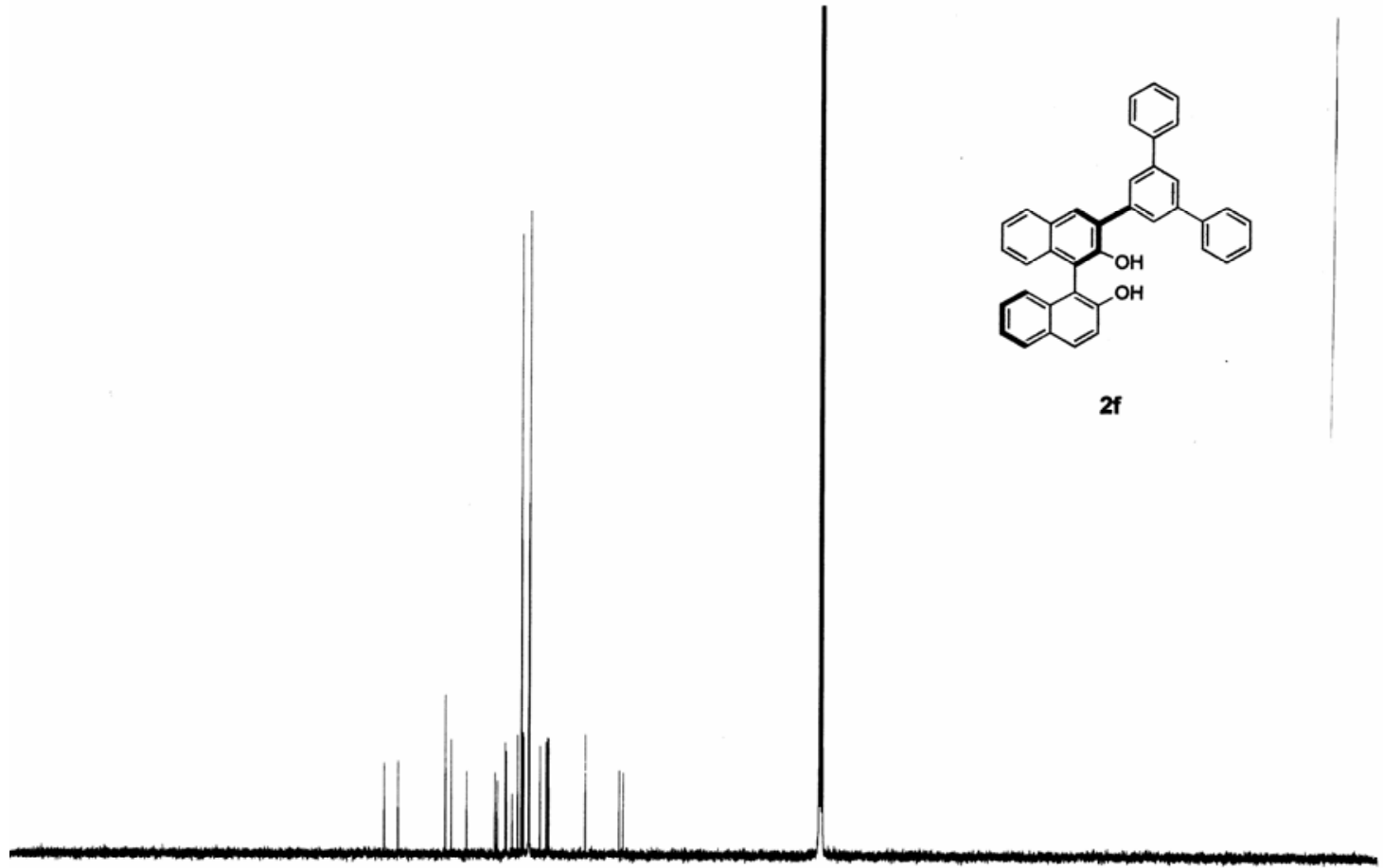

TD

SOLVENT

os

IDAES $\quad 0.458222 \mathrm{~Hz}$

1. $0912244 \mathrm{sec}$

6.650 usec

6.00 usec

$\begin{array}{lr}\text { TE } & 296.8 \mathrm{~K} \\ \text { D1 } & 0.50000000 \mathrm{sec}\end{array}$

ICAEST $0.0000000 \mathrm{sec}$

MCWAK $\quad 0.01500000 \mathrm{sec}$

NUC1

$13 \mathrm{C}$
$\mathrm{P}_{1}$

$\begin{array}{lr}\text { PL1 } & -2.00 \mathrm{~dB} \\ \text { SF01 } & 125.7703643 \mathrm{MHz}\end{array}$

CPDPAG CHANNEL f2 ...........

CPOPAG2 waltz16

$\begin{array}{lc}\text { NUC2 } & 1 \mathrm{H} \\ \text { PCPO2 } & 100.00 \mathrm{usec}\end{array}$

PL2 $\quad-6.00 \mathrm{OB}$

$\begin{array}{lr}\text { PL13 } & 13.74 \mathrm{OB} \\ \text { PF } & 500.1320005 \mathrm{MHz}\end{array}$

F2 - Processing paraneters

SI 32768

$\begin{array}{lr}\text { SF } & 125.7577932 \\ \text { NOW } & \text { EM } \\ \text { SS8 } & \text { O }\end{array}$

$\begin{array}{lc}\text { SSB } & 0 \\ L B & 1.00 \mathrm{~Hz} \\ G \mathrm{~B} & 0\end{array}$

10 NMA Dlot paraneters

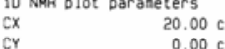

$\begin{array}{lr}\text { Cr } & 0.00 \mathrm{~cm} \\ \text { Fip } & 219.359 \mathrm{cpm}\end{array}$

$\begin{array}{ll}=1 & 27586.10 \mathrm{~Hz} \\ =2 \mathrm{P} & -19.434\end{array}$

$\begin{array}{ll}-19.434 & \mathrm{DDm} \\ F 2 & -2443.93 \mathrm{~Hz}\end{array}$

$\begin{array}{lr}\text { PPMCM } & 11.93963 \mathrm{DDm} / \mathrm{cm} \\ \mathrm{HZCM} & 1501.50146 \mathrm{~Hz} / \mathrm{cm}\end{array}$

Current Data Parameters
NAME
21E-236-PL2

EXPE

PROCNO

F2 - Acquisition Parameters

$\begin{array}{ll} & \\ \text { Date_ } & 20051210\end{array}$

Time

INSTRUM ar $\times 500$

PAOBHO I Th MUItinuc

290930
PUDAOG
TD

\begin{tabular}{ll} 
SOLVENT & 65536 \\
NS & CDC13 \\
\hline
\end{tabular}

SWH $\quad 30030.029 \mathrm{~Hz}$

$\begin{array}{ll}\text { FIORES } & 0.458222 \mathrm{~Hz} \\ A Q & 1.0912244 \mathrm{sec}\end{array}$

$\begin{array}{ll}A Q & 1.0912244 \\ \text { AG } & 10321.3\end{array}$

16.650 usec

296 . $x$

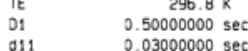

NCAEST $\quad 0.00000000 \mathrm{sec}$

MCWAK $\quad 0.01500000 \mathrm{sec}$

NUC1

$\begin{array}{lr}P_{1} & 5.70 \text { use } \\ P_{11} & -2.00 \text { of }\end{array}$

SF $01 \quad 125.7703643$ dB

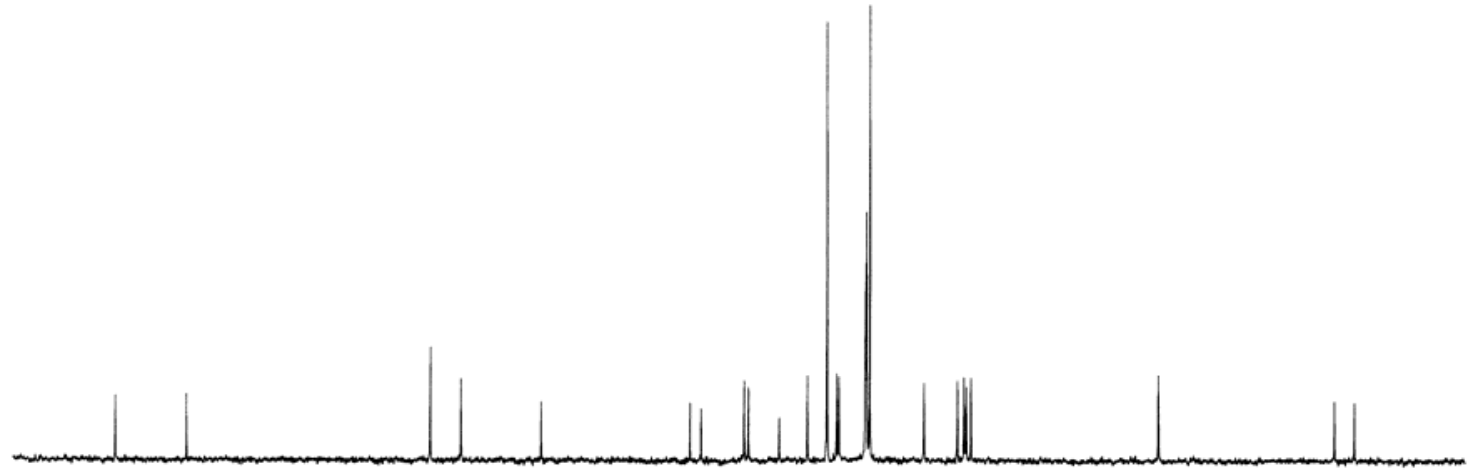

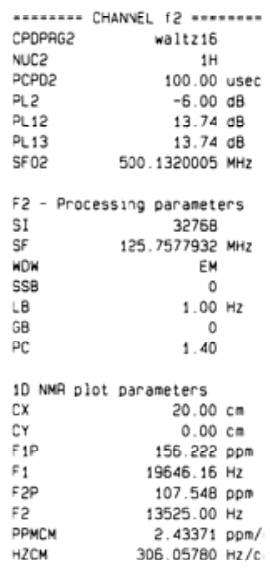



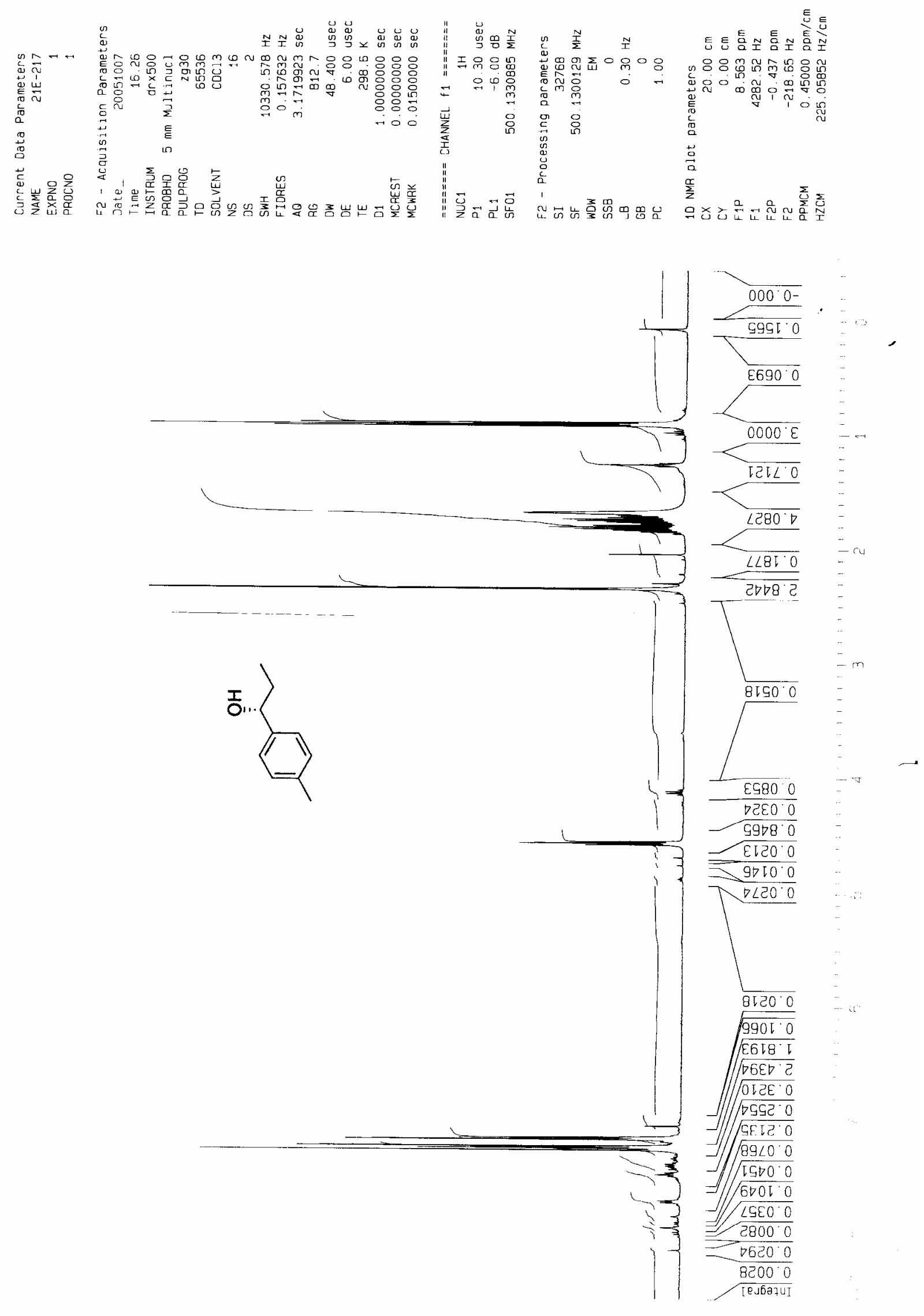

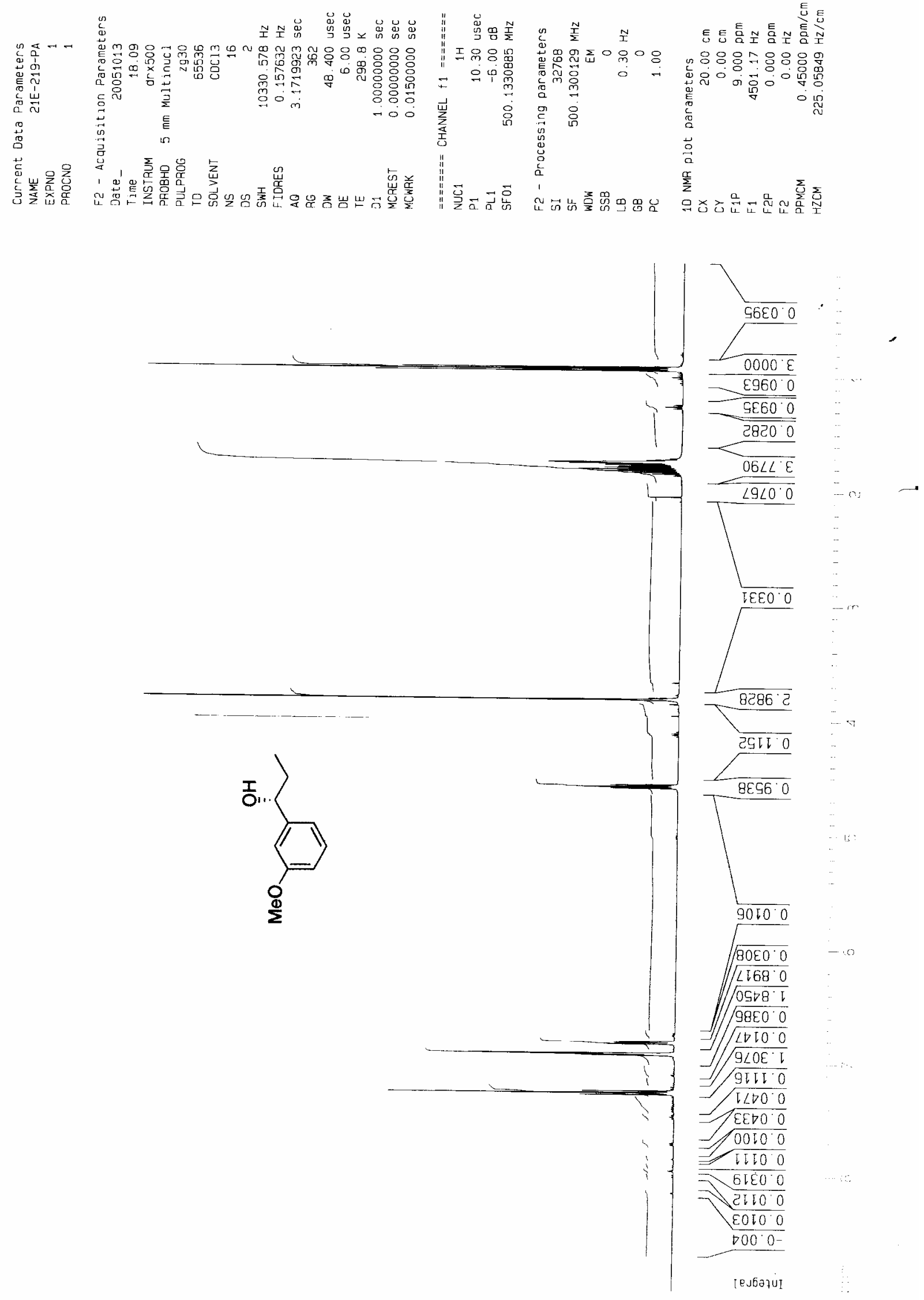

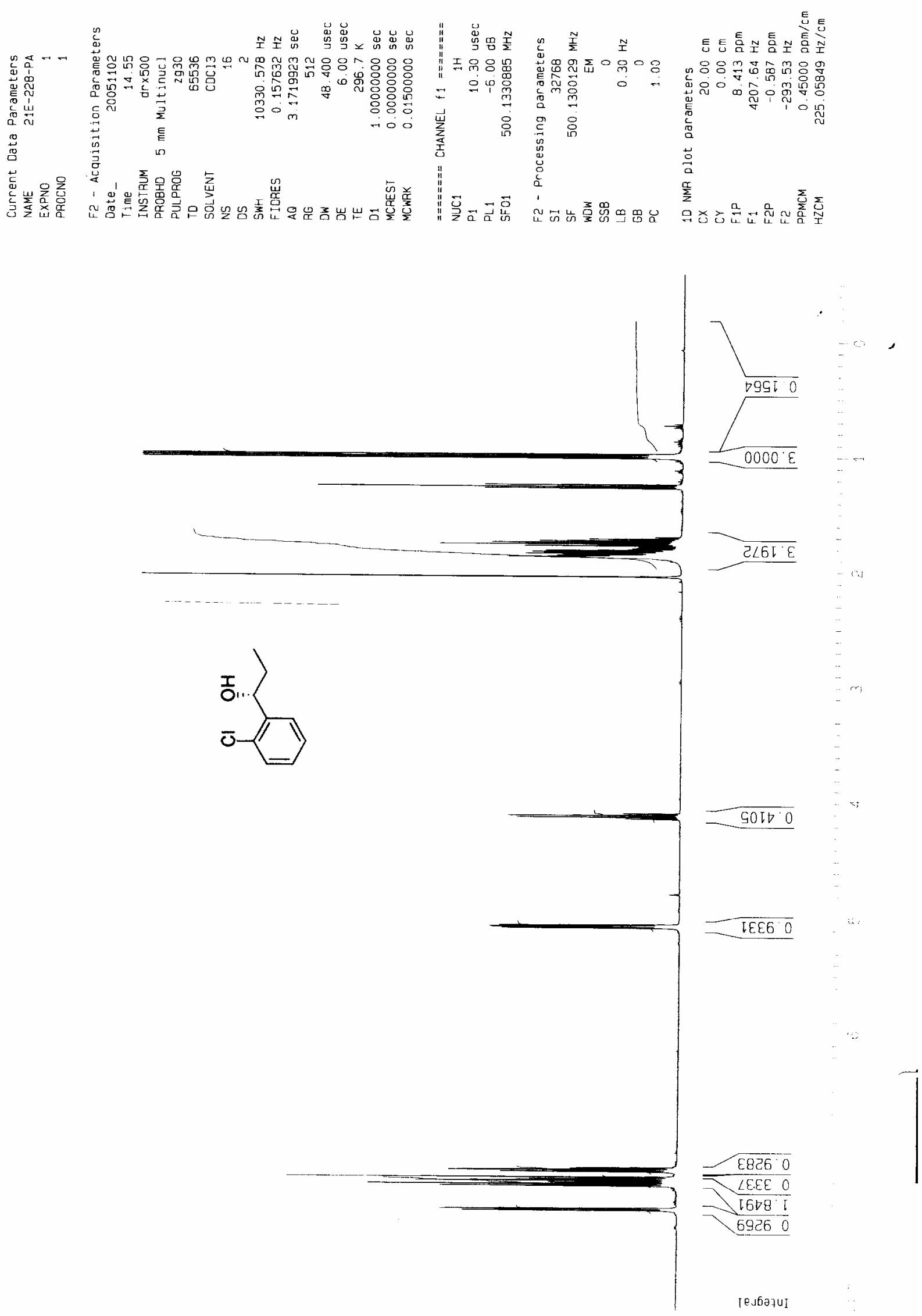

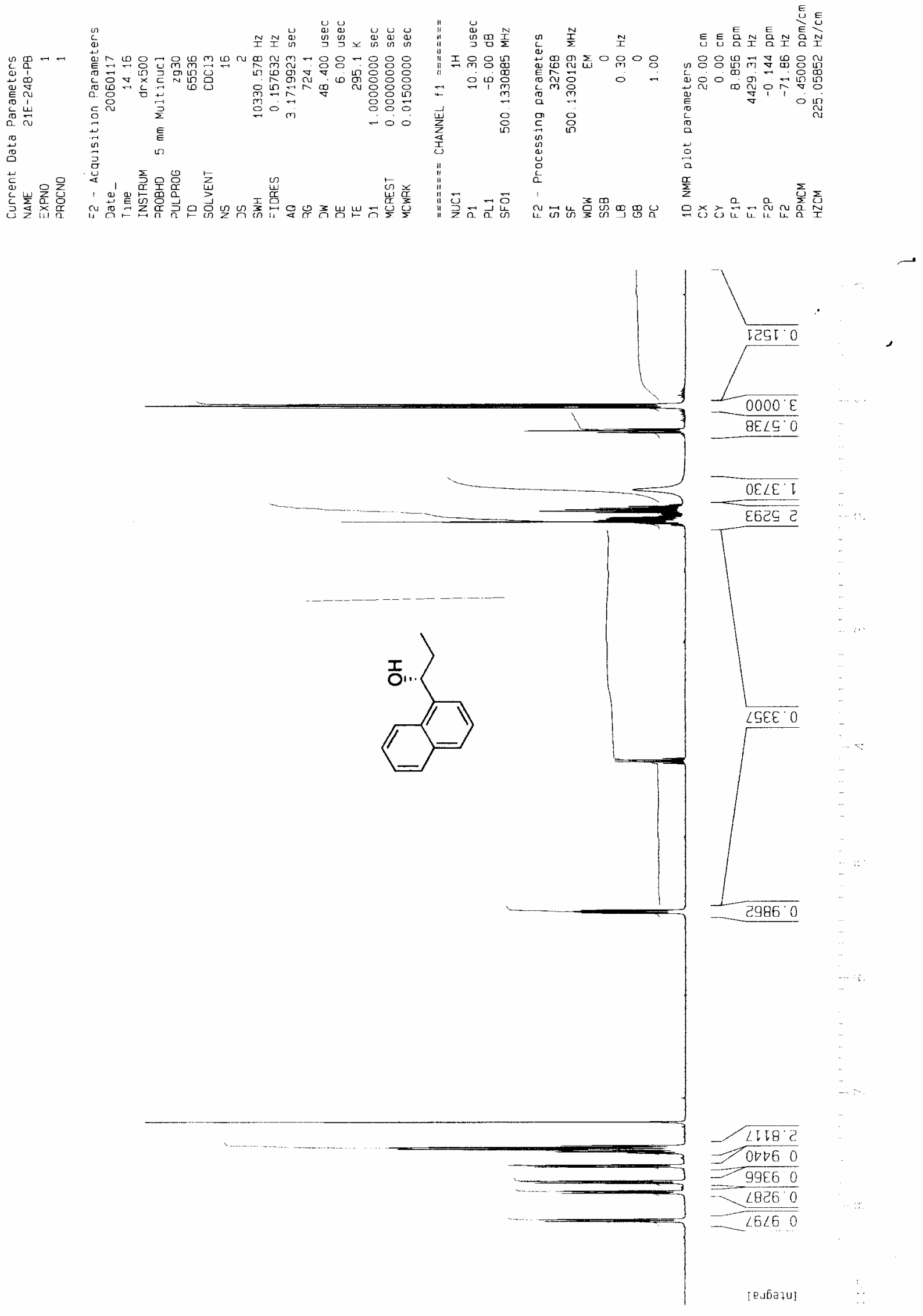

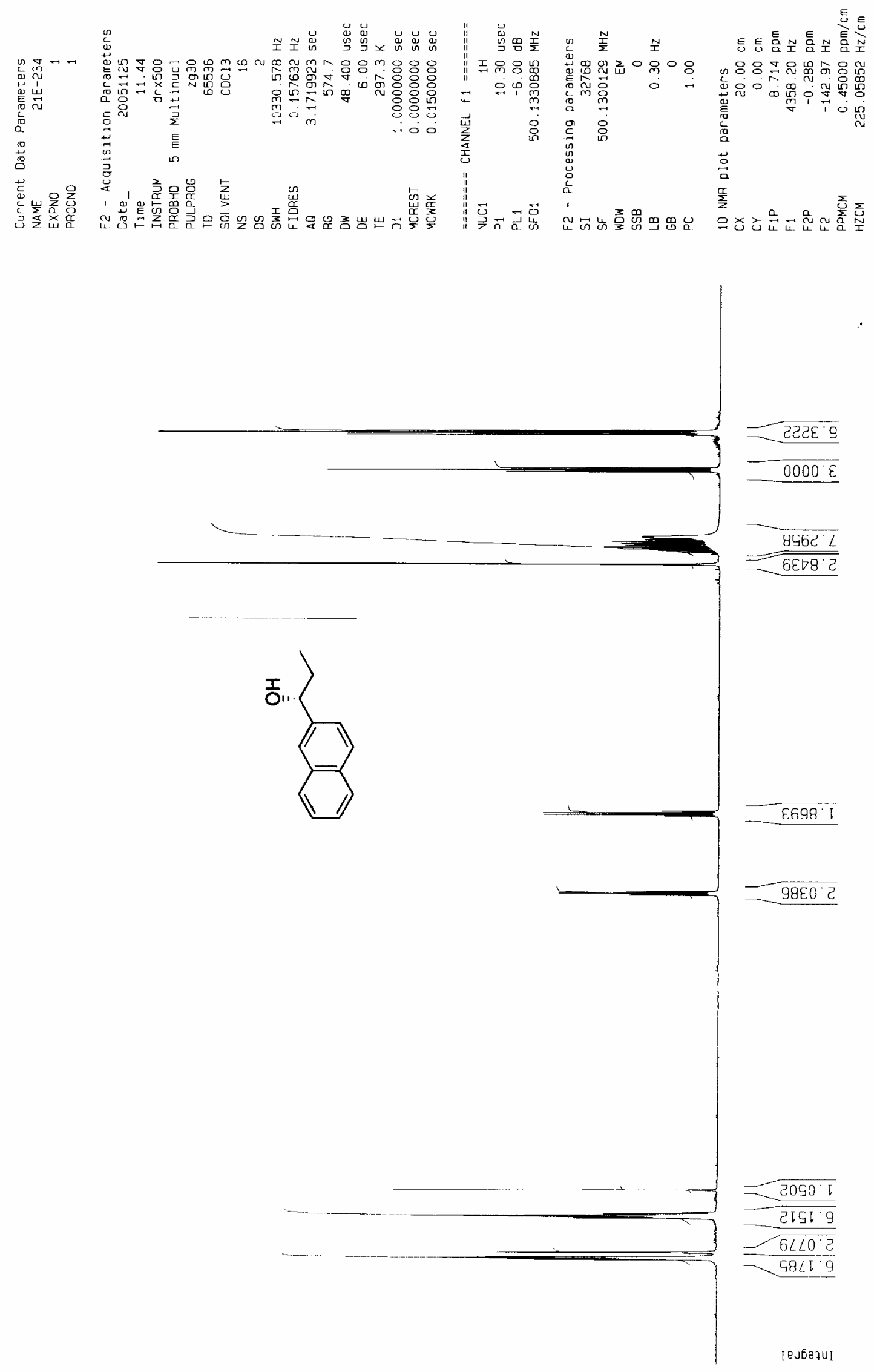

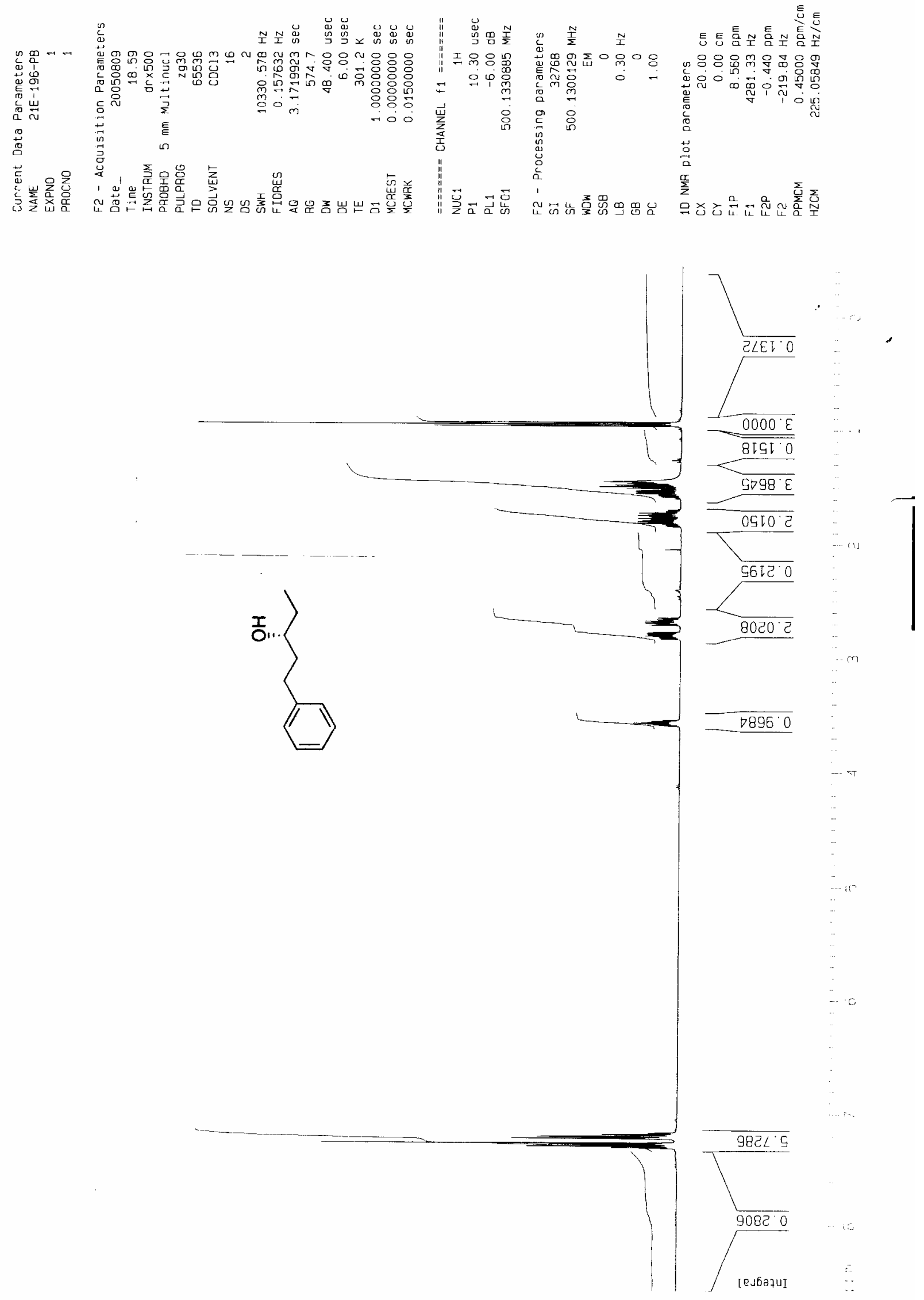

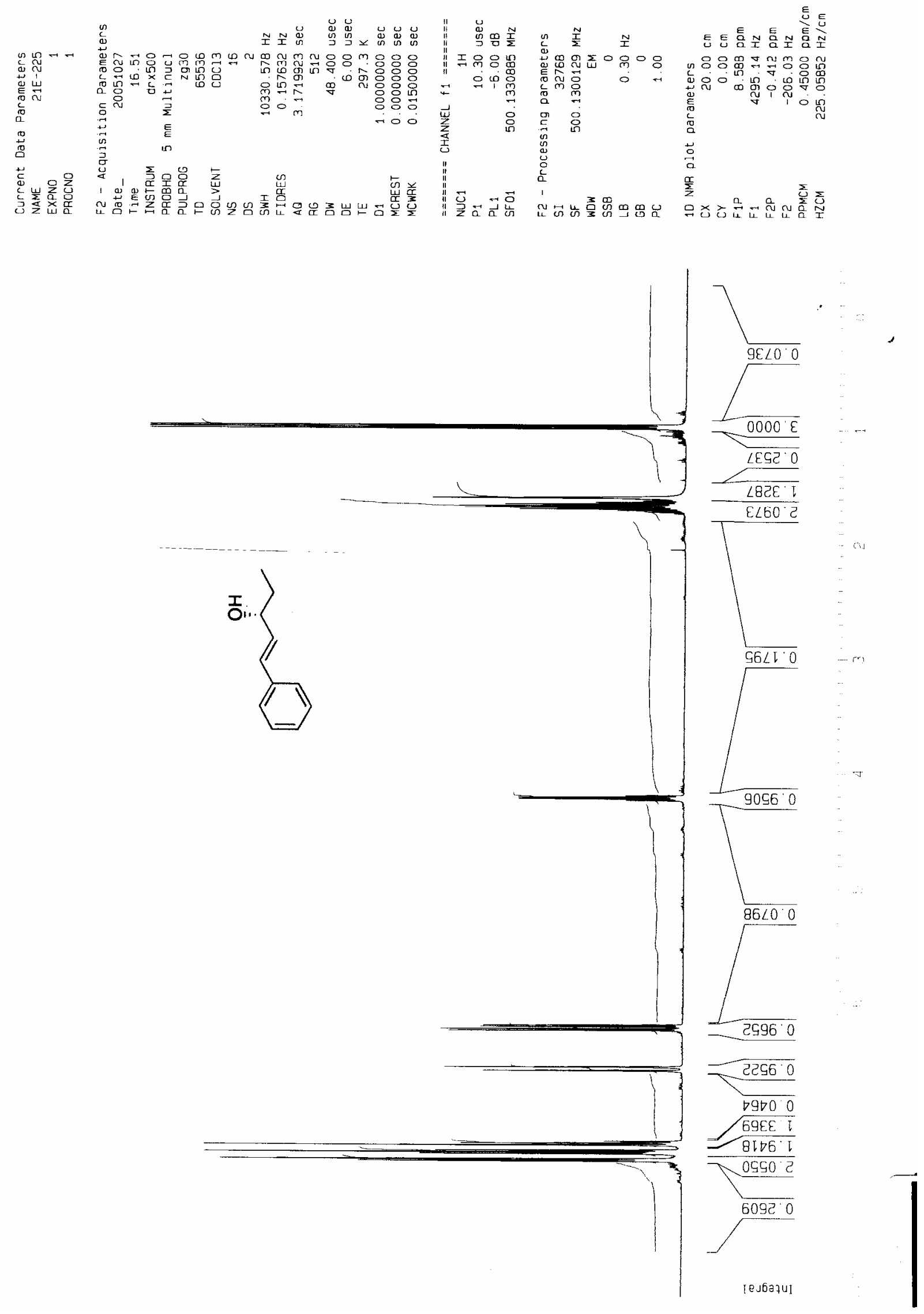